\title{
KSFC - REAL PROMOTER OF SERVICE ENTREPRENEURSHIP
}

\author{
A.S. Laxmisha*
}

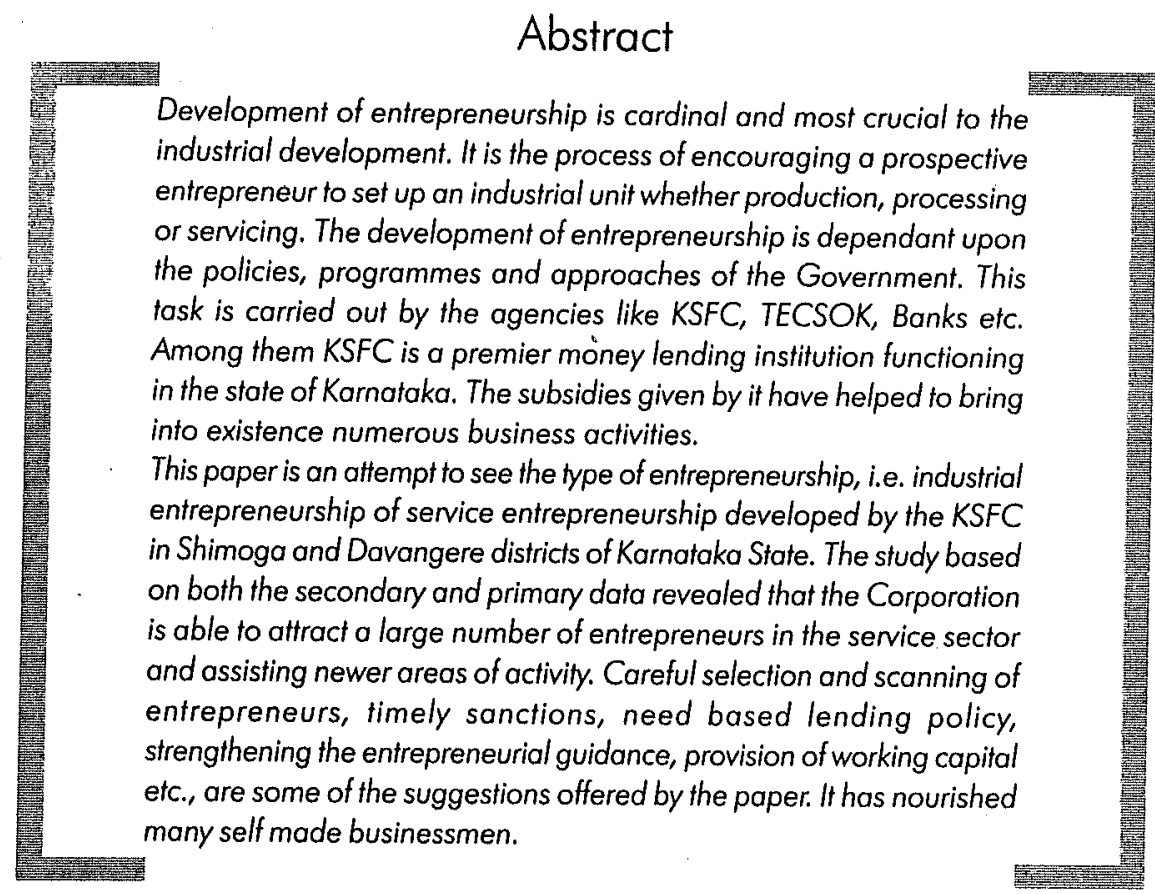

\footnotetext{
* Lecturer in Commerce, Lal Bahadur College, Sagara, Shimoga District.
} 
The development of entrepreneurship has become a movement in India. It is cardinal and more crucial to industrial development than any other economic factor. It has got added relevance due to massive unemployment of both educated and uneducated.

In a broad sense, development of entrepreneurship refers to all those activities undertaken to encourage a prospective entrepreneur to set up an industrial unit whether production, processing or servicing. In a narrow sense, it refers to the process of bringing out the "entrepreneur" in an individual. In other words, instilling in a person the urge to setup an industrial unit or undertake the entrepreneurial activity, and providing him with training in all aspects of establishing and managing an industrial enterprise. Entrepreneurship Development (ED) is the outcome of the fact that individual ideas can be developed and converted into action through an organised and systematic programme for the entrepreneur. The development of entrepreneurship is dependent upon the policies, programmes and approaches of the government. The government is discharging its role in ED by providing financial assistance and by undertaking various promotional activities. These two tasks are carried out by the agencies/institutions like KSFC, Tecsok, Commercial Banks, KSSIDC, etc. Among them, KSFC is engaged in developing the entrepreneurship by providing financial assistance to the entrepreneurs. The assisted entrepreneurs may engage themselves in production / processing activities and servicing activities. Depending upon the type of activity in which they are engaged, the entrepreneurship is classified as trading entrepreneurship, industrial entrepreneurship and servicing entrepreneurship. Vasanth Desai in a study of entrepreneurial functions mentioned that Britain, due to geographical limitations has developed trading entrepreneurship.

Keeping these things in mind, this paper is prepared to analyse the type of entrepreneurship developed by KSFC in the district of Shimoga (all the taluks) and Channagiri and Honnali taluks of Davangere district of Karnataka state. To achieve this purpose the data is collected from the annual reports and operational statistics of KSFC. The study is based on secondary data pertaining to the period from 1990 91 to 1997-98. The study is conducted by analysing the sector-wise sanctions \& activity wise sanctions made by KSFC in the study area. Such a study revealed the following:

\section{Sectorwise Sanctions}

The KSFC provides financial assistance to SSIs. vehicle operators (i.e. transport sector) and other activities such as hospitals, (for installation of electro-medical equipments in nursing homes), hotels, lodges, STD/ISD booths, consultancy senvicing units etc. The SSI sector includes many service rendering units like tyre retreading 
works, vehicle repairing and senicing, general engineering works, computer centres (data processing and software development works), screen printing etc. The detailed list of these activities is given in the activity - wise analysis made in the ensuring pages. Table 1 shows the sector-wise sanctions made by KSFC in the study area.

Table 1

\section{Sector wise Sanctions}

(Amount: Rs. in Lakhs)

\begin{tabular}{|l|r|r|r|r|r|r|r|r|}
\hline \multirow{2}{*}{ Year } & \multicolumn{2}{|c|}{ SSI } & \multicolumn{2}{c|}{ Transport } & \multicolumn{2}{c|}{ Others } & \multicolumn{2}{c|}{ Total } \\
\cline { 2 - 9 } & No. & Amount & No. & Amount & No. & Amount & No. & Amount \\
\hline $\begin{array}{l}\text { Grosssandions } \\
\text { trom 1990-91 } \\
\text { to 1997-98 }\end{array}$ & & & & & & & & \\
Percentagetototal & 1107 & 3599.17 & 932 & 1783.68 & 176 & 392.02 & 2215 & 5774.87 \\
\hline
\end{tabular}

Source: KSFC, Shimoga.

The analysis of Table 1 reveals that the SSI sector continued to bag the major portion of KSFC's resource in terms of amount (i.e. 62.32 percent of total amount sanctioned) but it is less than 50 percent in term of number of sanctions (i.e. 49.98 percent of total number of sanctions.) To be more precise, the entrepreneurs in the service sector i.e., transport and other sector have received 37.68 percent of the total sanctions in terms of amount and 50.02 percent in terms of number of sanctions, (i.e., 1108 sanctions out of 215 sanctions made during the period under study). Some of the SSI entrepreneurs are also in the service sector and their specific share in the service sector (both in terms of number and amount) is given in detail in the analysis of activity - wise sanctions made by KSFC.

\section{Activity-wise Sanctions}

Depending upon the nature of activity in which the assisted entrepreneurs/units are engaged, they are classified into two categories, viz, production and processing activity/units band servicing activity/units. In the study area the assistance is given by KSFC for the following types of senvice-oriented activities or units.

1. To purchase transport vehicle

2. Hotel Industry including lodges

3. Vehicle repairing and servicing 
4. Tailoring and laundrying

5. Automobile service centres

6. Refrigerator repairs

7. Weighing of loaded vehicles

8. Ornament cutting works

9. Eye-testing centres

10. Architect consultancies

11. Tyre retreading works

12. STD/ISD booths

13. Cable T.V. Networks

14. General engineering works

15. Beauty parlours

16. Xerox centres

17. To purchase road rollers

18. Godown construction

19. Screen printing

20. Ultra sound scanning

21. Vehicle wheel alignment (Computerised)

22. To instal electro-medical equipments in nursing homes

23. Acquisition of delivery vans by marketing entrepreneurs

24. Hi-Tech video modeling and videograph

25. Computer centres including software development

26. Diesel pump over rolling and servicing

27. Income tax and sales tax consultancy services 
Table 2 shows the activity-wise sanctions made by KSFC during the period under study.

Table 2

\section{Activity-wise Sanctions}

(Amount : Rs. in Lakhs)

\begin{tabular}{|l|c|c|c|c|}
\hline \multirow{2}{*}{$\begin{array}{l}\text { Type of the Activity } \\
\text { Units (Type of } \\
\text { Entrepreneurship) }\end{array}$} & \multicolumn{2}{|c|}{$\begin{array}{c}\text { Gross Sanctions from } \\
1990-91 \text { to 1997.98 }\end{array}$} & \multicolumn{2}{|c|}{$\begin{array}{c}\text { Percentage share to } \\
\text { total in terms of }\end{array}$} \\
\cline { 2 - 5 } & No. & Amount & No. & Amount \\
\hline $\begin{array}{l}\text { Production and } \\
\text { processing activity/ } \\
\text { units (Industrial } \\
\text { Entrepreneurship) }\end{array}$ & 956 & 3368.48 & 43.16 & 58.33 \\
\hline $\begin{array}{l}\text { Servicing activity/ } \\
\text { units (Service } \\
\text { Entrepreneurship) }\end{array}$ & 1259 & 2406.39 & 56.84 & 41.67 \\
\hline Total & 2215 & 57774.87 & 100.00 & 100.00 \\
\hline
\end{tabular}

Source: KSFC, Shimoga

Note: Sanctions under VISHWA Scheme and Head Office Sanctions excluded.

Table 2 shows that sanctions to servicing activity exceeds processing activity. It is not only shows the existence of a large number of entrepreneur engaged in service industry (in the study area). The requirement of Meagre capital for these enterprised is the reason that KSFC has been able to keep so many of these businessmen.

\section{Major Findings}

The analyses of the above two table reveals the following results:

1. The analysis of sector wise sanctions followed by activity-wise sanctions shows the emergence of a large number of entrepreneurs in the servicing line due to the development of servicing entrepreneurship

2. It is revealed that the nature of activities in the production and processing area (i.e. industrial entrepreneurship) involves huge cash outlay. Hence they are enjoying lion's share in the KSFC's assistance in terms of amount. But 
number-wise, the corporation played a major role in the development of service entrepreneurship in the study area.

3. The share of service entrepreneurs in the sanctions of KSFC (number-wise) shows the distribution of service entrepreneurs in big number in the study area. The requirement of meagre capital by these entrepreneurs is the major reason for their lower share in the amount sanctioned by KSFC. It shows the distribution of smaller entrepreneurs in the study area, who are the real backbone of the country and to some extent the industrial entrepreneurs also.

4. The list of assisted units reveals the existence of activities like nursing homes, electro-medical equipment installation, $x$-ray units, computer services, beauty parlours, hotels, bar and restaurants, lodges and such other newly allowed sectors in the portfolio of the corporation. This is to significant extent the result of a deliberate policy followed by the Corporation in the recent years.

To conclude, the change in the life style of the human being (i.e. mechanical life in urban/rural areas, attraction towards materialism on a large scale etc.) has increased the demand for servicing activities. The requirement of meagre capital to the activities in the servicing line (as the study has revealed) is positive to both the entrepreneurs and KSFC. The KSFC can use this as an opportunity to enhance its base in the State and to solve unemployment problem also. But what is also required is careful selection and screening of entrepreneurs, timely sanctions, follow-up assistance, simplification of legal formalities to avail loans, need based lending policy, provision of working capital, strengthening of entrepreneurial guidance, relaxing the promoter's minimum contribution margin to financially weak entrepreneurs (i.e. fixation of promoters minimum contribution by considering his financial base and not the area in which he is functioning and researching of newer service oriented activities. This would offer scope for improvement in the present services of KSFC. If these suggestions are implemented in good faith, it would go a long. way in strengthening the service entrepreneurship base in the state of Karnataka and KSFC can become No. 1 in the country. 